Article

\title{
Segmentation of Coffee Consumers Using Sustainable Values: Cluster Analysis on the Polish Coffee Market
}

\author{
Grzegorz Maciejewski ${ }^{1, *(\mathbb{D}, \text { Sylwia Mokrysz }}{ }^{2}$ and Lukasz Wróblewski ${ }^{3, *(1)}$ \\ 1 Department of Market and Consumption, Faculty of Economics, University of Economics in Katowice, \\ 40-287 Katowice, Poland \\ 2 Mokate SA, 43-450 Ustroń, Poland; sylwiamo@gmail.com \\ 3 Department of Management and Production Engineering, WSB University, \\ 41-300 Dabrowa Górnicza, Poland \\ * Correspondence: grzegorz.maciejewski@ue.katowice.pl (G.M.); lwroblewski@wsb.edu.pl (Ł.W.); \\ Tel.: +48-501-615-720 (G.M.); +48-692-344-057 (Ł.W.)
}

Received: 20 December 2018; Accepted: 21 January 2019; Published: 24 January 2019

\begin{abstract}
Producers and retailers are the driving force behind the adoption of the idea of sustainability. It has been found that while preparing their product range offer, many still pay attention to the same set of criteria: size of the customers' earnings, how often they shop, and how much they buy when shopping. In general, sustainable values applied by consumers in their purchasing decisions are rarely taken into account in consumer segmentation. The aim of this study is to recognize if values such as environmental protection, producers' ethical behavior, fair trade or maximizing the utility function of consumption are important factors in the purchasing process of coffee and if they can be used as segmentation variables. The discussed findings come from a standardized online survey conducted on a sample of 800 Polish coffee consumers in July 2018. The obtained results are discussed by employing multi-dimensional analyses, such as exploratory factor analysis (EFA) and cluster analysis (CA). In consequence, six segments of coffee consumers are identified and described: "responsible, aspiring to be connoisseurs", "loyal coffee enthusiasts", "pragmatic users", "coffee laypersons", "sophisticated connoisseurs", and "consumerists, connoisseurs, but not at any price". Among the identified segments, the most often indicated sustainable consumption values refer to "responsible, aspiring to be connoisseurs", and the least often to "consumerists, connoisseurs, but not at any price". The conclusions may be used by manufacturing and trade enterprises operating in the coffee market to respond to the identified needs and expectations of consumers.
\end{abstract}

Keywords: market segmentation; coffee market; consumer behavior; sustainable consumption; sustainable values; factor analysis; cluster analysis

\section{Introduction}

The classic understanding of the coffee market reduces its definition to the sum of the trading relationships between sellers offering coffee beans and coffee products, and the buyers, representing the demand for these products. It includes both subjective (who participates in the trading process) and the objective (what is the object of trade) aspects [1]. With regard to the coffee market, the subjects are the growers, the suppliers of coffee beans, dealers, producers of roasted coffee beans (coffee roasters), coffee processors, and coffee distributors (wholesalers, retailers, service providers), who are the supply side of the market, as well as the buyers of coffee (coffee consumers), the demand side. The objects of the coffee market are green and roasted coffee beans, as well as various products based on these 
grains (e.g., coffee beans, ground coffee, instant coffee, cappuccino) and the hybrid products offered by businesses serving coffee in the form of ready-to-drink beverages [2,3].

The largest supplier of coffee beans in the world is South America (71.4 million $60 \mathrm{~kg}$ bags of coffee in 2017) and, more precisely, Brazil, with an annual production volume of about 55 million bags in 2017. While the supremacy of Brazil, with its huge plantations covering a total of about 2 million hectares, remains unwavering, the situation is more fluid when ranking the other positions. According to the geographical breakdown, aside from Brazil, the following should be included as the world's largest coffee producers in 2017: Vietnam (25.5 million bags), Colombia (14.6 million), Indonesia (11.5 million), Honduras (7.5 million), and Ethiopia (7.3 million). Further down the rankings, the following countries have also ranked in recent years: India (5.2 million), Uganda (5.0 million), Peru (4.2 million) and Mexico (3.8 million) [4].

The largest portion of global coffee production (approximately 159 million bags) goes to the European market (approximately 52 million bags), followed by the emerging Asia and Oceania markets (approximately 35 million bags) and the North American market (approximately 30 million bags) [5]. According to the International Coffee Organization in London, the aggregate demand for coffee beans in the world during the 2017/ 2018 cultivation season will amount to 158,953,000 bags of coffee, exceeding the production of coffee beans by 23,000 bags [4].

Additionally, a 2018 report from the Mintel Group Ltd. [4,5] showed that the global coffee market is still growing, with the growth trend being particularly visible in Asia where the residents traditionally drink tea, but are slowly changing their habits and are starting to consume more and more coffee. The culture of drinking coffee is also developing in the countries of Latin America, North Africa, and the Middle East, which in turn translates into more sales. In mature European markets (including Poland), growth is already much slower. In North America, market development has mainly been driven by the increase in the consumption of coffee pods and ready-for-consumption chilled coffee.

In Poland, coffee is ranked fourth in the food category in terms of annual turnover and the value of the coffee market is still growing [6]. Total coffee sales in Poland in 2017 amounted to nearly USD 1 billion, an increase of approximately $3.7 \%$ in comparison to 2016 . The average annual consumption of coffee per capita in Poland is about $2.85 \mathrm{~kg}$. In comparison, annual consumption is $12 \mathrm{~kg}$ in Finland, $12 \mathrm{~kg}$ in Sweden, $11 \mathrm{~kg}$ in Denmark, and $9 \mathrm{~kg}$ in the Netherlands and Norway [7].

Consumer groups, whose needs and expectations are unsatisfied or not satisfied sufficiently, may become an area of activity for coffee producers. Determining whether these groups can become a viable market and the decisions to focus activity on a specific market segment are referred to as the selection of target market segments [8,9].

Therefore, the research questions we investigated were as follows:

RQ1: Are values such as environmental protection, the ethical behavior of producers, fair trade, or maximizing the utility function of consumption so important in the purchasing process in the coffee market that they can be used as segmentation variables? And hence:

RQ2: Can we talk about the existence of a responsible consumer segment of the coffee market that is made up of consumers who are driven by sustainable values, who expect not only good quality products, but products made with respect for sustainable values?

RQ3: How big is this market segment?

RQ4: Who are the consumers who are guided by sustainable values in their choices?

This study tried to follow the line of research defined by Wedel and Kamakura [10], Paco and Raposo [11], Obilo and Alford [12] by focusing in detail on using sustainable values as segmental variables to distinguish a segment of coffee consumers who are guided in their purchasing decisions by sustainable values, and by determining the size and structure of this segment.

This paper is organized as follows: Section 2 defines the theoretical framework and Section 3 presents the methodology of the research undertaken. First of all, it presents the course of the surveys conducted, followed by the applied data analysis methods (exploratory factor analysis and cluster analysis). Section 4 presents the research results and the analysis undertaken by the authors, namely 
the description of six separate segments of coffee consumers. Section 5 discusses the research results obtained. Section 6 presents the conclusions from the conducted research and analyses as well as the main limitations and future research directions.

\section{Literature Review}

In the 21st century, sustainable consumption, including the sustainable consumption of coffee, is of great interest to economists. Treating economics as "the science of the rational disposal of scarce resources having an alternative use" [13], one can notice the interrelations between sustainable consumption and economics, especially within subdisciplines like environmental economics, ecological economics, and the economics of sustainable development, which has increasingly crystallized in the last twenty years. There are also clear connections between sustainable consumption and management sciences, especially marketing, which includes sustainable, ecological, and social marketing [14,15]. However, despite the high interest of scientists in the problems of the sustainable development economy, the problem of sustainable values guiding coffee consumers in their purchasing decisions has been relatively rarely raised. These values constitute a set of factors that make up one of the goals of the so-called green economy, affecting the growth of human welfare and social equality while reducing environmental risk and the consumption of natural resources [16,17]. One of the assumptions of this economy is the change in the manner of production and consumption of products. As noted by Mont and Plepys [18], this approach has dominated political and scientific thinking, particularly since the Earth Summit in Johannesburg in 2002, which is reflected in the concept of sustainable consumption and production (SCP). In SCP, the focus is on products and services, as well as consumer responsibility for buying environmentally sustainable products $[19,20]$. In accordance with the concept of SCP, the European Commission postulates increasing efficiency while consuming less raw materials, reducing costs, and limiting the impact on the environment [21]. For example, in Poland, activities for the implementation of sustainable consumption standards and promoting purchasing decisions based on sustainable values have been addressed for many years by the Polish Green Network organization, which associates environmental organizations operating in major Polish cities. This organization promotes the concept of conscious (responsible, sustainable) consumption signifying making wise consumer choices. Such consumption means having a different perspective on the money available to consumers. Money is an important asset, which consumers can use to vote for or against a particular matter [22]. According to Evans [23], purchasing products based on sustainable values means buying sustainable products, i.e., products whose production does not involve the violation of human and labor rights, degradation of the natural environment, and harmful impacts on human health. The production of these type of products (including coffee) actively contributes to the improvement of people's quality of life and protecting the natural environment. According to the assumptions of the Ministry of Entrepreneurship and Technology [24], sustainable products are products based on sustainable values, in particular:

- Safe products meeting international environmental and ethical standards at all stages of their life cycle;

- Products whose manufacturing and usage positively affects both consumers and the local community;

- Products whose production and distribution process stimulates the service sector, which improves the situation in the labor market (reduction of unemployment);

- Products that have reliable information attached to them regarding environmental and social aspects, and their safe use, as well as processing and disposal;

- Products that are equal to or outperform conventional products in terms of quality and usability during use.

The purchase of sustainable products through consumer behaviors based on sustainable values will therefore be an important part of the production and consumption chain because consumers make 
the final choice of products. According to Caeiro et al. [25], coffee consumers should be seen as part of the solution and not as part of the problem in promoting sustainable consumption because their values and willingness to participate are the basis for the actions taken, both on an individual and public level. According to Balderjahn et al. [26], the key to understanding the standards of sustainable consumption in the coffee market is to analyze consumer behavior and then segment it properly.

This choice requires the use of an appropriate procedure that allows the entire market to be divided into smaller areas or segments, which include consumers guided by the same values with similar needs and similar characteristics of behavior or motivation. The application of the appropriate procedure also allows the assessment of which isolated segments are distinguished by the highest market opportunities or potential risks [27].

Due to the varied objectives of segmentation research in both the source literature and in practice, various market segmentation procedures have been proposed. The most common are procedures such as [28-31]:

- The traditional a priori segmentation procedure;

- E.J. McCarthy's simplified segmentation procedure;

- The segmentation procedure with an analytical and decision-making character; and

- The five-stage procedure for determining segments in a given market developed by M. McDonald and I. Dunbar.

In the segmentation of the coffee market, which is a market characterized by a very large, heterogeneous group of recipients, it seems most appropriate to use the analytical and decision-making procedure. The procedure is derived from E.J. McCarthy's simplified segmentation and is based on the four main steps [32-34]:

- Selection of segmentation criteria;

- Development of segment profiles;

- Development of segment attractiveness assessment criteria;

- Selection of target segments.

The selection of segmentation criteria is made after defining the product and the market to be segmented, and determining the needs and expectations of potential buyers. The next step of the procedure is to examine and evaluate potential market segments, which requires the preparation of so-called segment profiles. This step is about the development of qualitative and quantitative characteristics to assess the attractiveness (profitability) of the enterprise for future target (operational) segments. The choice of target segments and the planning of marketing activities dependent on the adopted variant of the market segmentation strategy is the last step of the procedure.

Due to the fact that the coffee market is internally too diverse to distinguish its most important segments, it is necessary to apply many segmentation criteria [34-37]. In the source literature, market classification according to general and specific criteria, as well as according to objective and subjective criteria [35-37], is the most common. The general criteria include those that apply to every consumer, a coffee consumer in this case, regardless of the market situation, and specific criteria refer to a specific market situation affecting consumer behavior as a subject of demand. Objective criteria include those criteria that can be measured in an indisputable way (e.g., age, gender), while subjective criteria have to be arrived at on the basis of research results (e.g., lifestyle, coffee brand preferences, attitude toward sustainable consumption) [38,39].

In the source literature it is difficult to find segmentation criteria referring to sustainable development or sustainable consumption. Thus, there are no studies that have taken sustainable values in the segmentation criteria in the coffee market into account. Therefore, this article is an attempt to fill the research gap in this field and to find the answer to the question of whether sustainable values may constitute segmental variables in the coffee market and whether there is a segment of coffee consumers who are guided by sustainable values in their choices. 
The authors therefore put forward the following hypothesis: Sustainable values such as environmental protection, the ethical behavior of producers, fair trade, and maximizing the usefulness of consumption can be used as segmentation criteria in the coffee market. The relationship to these values differentiates consumer groups, therefore distinguishing a segment for which not only is a better quality of life important, but also the protection of the Earth's ecosystem and concern for the ability to meet the needs of future generations. Knowledge on the availability, measurability, and size of this segment may contribute to the wider implementation of a balanced product offer by producers and sellers operating in the coffee market.

To verify the truth of the hypothesis put forward, primary research was carried out with the participation of coffee consumers. The research methodology as well as the results and conclusions are presented in subsequent parts of this article.

\section{Methodology}

\subsection{Materials}

In order to confirm or reject the hypothesis, a standardized online survey was designed and conducted. The research conducted was quantitative. The research was completed in July 2018.

The research tool was a standardized survey posted on the website of the Ariadna Nationwide Research Panel, in which over 100,000 people from all over Poland are registered [40]. In the Ariadna nationwide research panel, participants must be aged 15-70. Minors, along with the application, must send a signed consent of their parents or legal guardians for their participation in the research. The consent must be written according to the following model: "I, the undersigned [first name and surname of the parent or legal guardian], as the legal guardian, hereby give my consent for the participation of [first name and surname of the minor person] in the Ariadna nationwide research panel." [date and signature of the parent or legal guardian]. [41]. The questions in the survey were formulated in the form of open, closed, and semi-closed questions and Likert scales. The reliability of the scales used in the study was confirmed by the Cronbach's alpha test. The test values obtained for all applied scales ranged from 0.7 to 0.9 . Prior to the research, the survey was tested (pilot run) to eliminate possible errors of the research tool and to assess its correctness and suitability to achieve the objectives of the study.

\subsection{Research Sample}

Coffee consumption was declared by $80 \%$ of Poles aged $16-64$ [42,43]. This represents a population of over 25 million consumers. In the case described, we looked for males and females who declared that they drank coffee at least once a day, were aged 16-64, and resided in Polish provinces. The size of the test sample was set at 800 . This sample size provided results with a measurement error of no more than $3 \%$, with a confidence level of 0.95 and estimated fraction size of 0.8 . This assumption was met; a total of 800 correctly and fully filled out questionnaires was received (Table 1).

Gender breakdown consistent with the ratio in the general population of Poland's inhabitants was assumed in this research. As a result, it involved 413 women and 387 men, which accounted for $51.6 \%$ and $48.4 \%$ of the sample, respectively. These were most often people living in towns of various sizes $(76.7 \%)$ with secondary $(45.8 \%)$ or higher education (39.6\%). The monthly net income per person in the respondents' households usually ranged from 301 to 500 euro (30.6\% of the respondents provided such answers). Most people consumed ground coffee (39.4\%) or instant coffee (34.1\%) once or twice a day $(65.1 \%)$ (Table 1$)$. 
Table 1. Characteristics of the research sample $(n=800)$.

\begin{tabular}{|c|c|c|c|}
\hline Specification & & Absolute Number & $\begin{array}{l}\text { Percentage of } \\
\text { the Tested } \\
\text { Sample }\end{array}$ \\
\hline \multirow{2}{*}{ Sex } & Female & 413 & 51.6 \\
\hline & Male & 387 & 48.4 \\
\hline \multirow{5}{*}{ Age } & $16-24$ & 160 & 20.0 \\
\hline & $25-34$ & 161 & 20.1 \\
\hline & $35-44$ & 159 & 19.9 \\
\hline & $45-54$ & 161 & 20.1 \\
\hline & $55-64$ & 159 & 19.9 \\
\hline \multirow{7}{*}{ Place of Residence } & Rural areas & 186 & 23.3 \\
\hline & Town with up to 20,000 residents & 108 & 13.5 \\
\hline & Town with $20,000-49,000$ residents & 100 & 12.5 \\
\hline & Town with $50,000-99,000$ residents & 106 & 13.3 \\
\hline & Town with $100,000-199,000$ residents & 94 & 11.8 \\
\hline & Town with $200,000-500,000$ residents & 107 & 13.4 \\
\hline & Town with over 500,000 residents & 99 & 12.4 \\
\hline \multirow{4}{*}{ Education } & Primary/lower secondary & 25 & 3.1 \\
\hline & Vocational & 92 & 11.5 \\
\hline & Secondary & 366 & 45.8 \\
\hline & Higher & 317 & 39.6 \\
\hline \multirow{6}{*}{$\begin{array}{l}\text { Monthly Net Income } \\
\text { Per Person }\end{array}$} & 200 euro or less & 99 & 12.4 \\
\hline & From 201 euro to 300 euro & 157 & 19.6 \\
\hline & From 301 euro to 500 euro & 245 & 30.6 \\
\hline & From 501 euro to 700 euro & 138 & 17.3 \\
\hline & From 701 euro to 950 euro & 94 & 11.8 \\
\hline & Above 950 euro & 67 & 8.4 \\
\hline \multirow{3}{*}{$\begin{array}{l}\text { Frequency of } \\
\text { Drinking Coffee }\end{array}$} & 3 times per day and more often & 190 & 23.8 \\
\hline & $1-2$ times per day & 521 & 65.1 \\
\hline & Once or several times a week & 89 & 11.1 \\
\hline \multirow{8}{*}{$\begin{array}{l}\text { Most Common Type } \\
\text { of Coffee Drunk }\end{array}$} & Coffee beans (whole beans) & 127 & 15.9 \\
\hline & Ground & 315 & 39.4 \\
\hline & Instant & 273 & 34.1 \\
\hline & Coffee mixes ( 2 in 1,3 in 1 ) & 16 & 2.0 \\
\hline & Instant cappuccino & 19 & 2.4 \\
\hline & Coffee in capsules (for espresso machine) & 15 & 1.9 \\
\hline & Coffee in sachets/pads (for espresso machine) & 13 & 1.6 \\
\hline & Instant wheat coffee/chicory & 22 & 2.8 \\
\hline
\end{tabular}

Data source: Collected by this research.

\subsection{Methods of Analysis}

\subsubsection{Validity of the Methods Used}

Multi-dimensional analyses were carried out to identify the main consumer segments of the coffee market: factor analysis and cluster analysis. Factor analysis aimed to reduce the originally occurring number of variables and create a new set of variables with the least possible loss of information contained in them. For this purpose, we decided to use exploratory factor analysis (EFA), which allows for a large number of studied variables to be reduced to a much smaller number of factors (principal components). The isolated principal components have a different substantive interpretation and retain a significant part of the information contained in the primary variables [44].

In turn, the objective of cluster analysis (CA) was the final determination of consumer segments of the coffee market, including the indication of segments of consumers guided by sustainable values in their choices.

Among the cluster analysis methods used in the process of market segmentation, hierarchical methods are often used most. In the course of the grouping procedure, several stages widely described 
in the literature [45] can be distinguished. The starting point is the situation in which each object represents one independent group or class, in other words, a single element cluster. There are as many clusters as there are objects. After each classification step, the number of classes decreases by one whereby the number of classes is reduced by combining two existing ones. There are $n-1$ classification steps. The procedure ends when all objects are in a single group [46]. The grouping process is usually represented using a binary tree, a dendrogram, which illustrates the hierarchical structure of the set of objects according to the decreasing similarity between them.

Due to the differences in the method of determining the similarity between objects combined into classes (clusters) and determining the distance between classes of objects in a multi-dimensional space, several grouping variants (algorithms) of agglomeration methods are distinguished in cluster analysis, which is reflected in their names: the nearest neighbor method, the farthest neighbor method, the center of gravity method, the median method, the group mean method, and Ward's method [45,47]. For the purpose of segmentation in marketing research, Ward's method is used quite often [48]. This is determined by the method of combining objects into clusters. In Ward's method, objects are combined that cause the smallest increase of the variance in the cluster, thus ensuring the highest homogeneity of the cluster [49]. In this method, the squared Euclidean distance is most often used as a measure of similarity between objects. This solution has a very valuable trait: when calculating the distance between objects, large differences in the values of the variables describing these objects are taken into account more strongly than in the situation of a small variation of the variables [45]. Unfortunately, like any method, Ward's method has its methodological drawbacks and limitations. In order to obtain more accurate results, the use of other classification methods in the same study, e.g., division methods and non-hierarchical methods is therefore recommended [50]. This was also carried out in this research by first using one of the hierarchical agglomeration methods-Ward's method applied with the squared Euclidean distance-and then the non-hierarchical k-means method.

\subsubsection{The Course of Analysis}

In the research conducted, the segmental analysis was based on behavioral criteria describing the respondents' attitudes and behaviors related to purchasing opportunities, sought after benefits, brand attachment, usage intensity, etc. The research took into account the attitude of the respondents to sustainable values, which are currently being strongly promoted by the protagonists of consumerism and apologists of sustainable consumption. Sustainable values were included in 6 statements out of 30, which were assessed by the study participants. The participants responded to the statements using a 5-point Likert scale, where a score of 1 meant "I strongly disagree" and a score of 5 meant "I strongly agree". Statements containing sustainable values corresponded to the model of sustainable consumption in the ecological, economic, and social dimensions [51-54]. These were presented as follows:

- I can pay more for coffee, which is a BIO product or is Fair Trade certified.

- When buying coffee, I always check who is the producer.

- I want to know how the coffee I drink was made.

- It is important for me that the packaging in which the coffee is sold is as environmentally friendly as possible.

- If the coffee has practical packaging, I can pay more for it.

- $\quad$ Large packages are better because they are more economical.

To elaborate on the data obtained in the research, the aforementioned multi-dimensional analyses were used, the basic feature of which is the possibility of analyzing many (more than two) variables at the same time. This makes it possible to create a uniform image of the consumer, going beyond many separate and often incomparable profiles that can be obtained based on standard statistical methods. When segmenting the market, EFA is usually performed first, where factors are initially unknown and 
are isolated by analyzing the values of random variables. In this study, this type of factor analysis was also used.

\subsubsection{Exploratory Factor Analysis}

After collecting the data from the surveys, EFA was carried out using the principal component method. Its purpose was to reduce the number of original variables and create a new set of these variables containing the least possible loss of information. The analysis was based on 30 statements regarding attitude toward coffee consumption. Five explanatory factors were obtained, totaling $54.6 \%$ of the variance of total variables (Table 2). The obtained factors were subjected to varimax rotation. This does not change the results of the analysis itself but, through the distribution of variance, it significantly affects the ease of the interpretation of the factors.

Table 2. Total explained variance and eigenvalues *.

\begin{tabular}{|c|c|c|c|c|c|c|c|c|c|}
\hline \multirow[b]{2}{*}{ Component } & \multicolumn{3}{|c|}{ Initial Eigenvalues } & \multicolumn{3}{|c|}{ Sum of Load Squares after Isolation } & \multicolumn{3}{|c|}{ Sum of Load Squares after Rotation } \\
\hline & Total & $\begin{array}{l}\% \text { of } \\
\text { Variance }\end{array}$ & Cumulative \% & Total & $\begin{array}{l}\% \text { of } \\
\text { Variance }\end{array}$ & Cumulative \% & Total & $\begin{array}{l}\% \text { of } \\
\text { Variance }\end{array}$ & Cumulative \% \\
\hline 1 & 8.803 & 29.342 & 29.342 & 8.803 & 29.342 & 29.342 & 7.683 & 25.610 & 25.610 \\
\hline 2 & 2.858 & 9.526 & 38.868 & 2.858 & 9.526 & 38.868 & 2.894 & 9.647 & 35.257 \\
\hline 3 & 2.259 & 7.532 & 46.400 & 2.259 & 7.532 & 46.400 & 2.882 & 9.606 & 44.864 \\
\hline 4 & 1.226 & 4.086 & 50.486 & 1.226 & 4.086 & 50.486 & 1.535 & 5.116 & 49.979 \\
\hline 5 & 1.220 & 4.065 & 54.551 & 1.220 & 4.065 & 54.551 & 1.372 & 4.572 & 54.551 \\
\hline$\ldots$ & $\ldots$ & $\ldots$ & $\ldots$ & & & & & & \\
\hline 30 & 0.275 & 0.915 & 100.000 & & & & & & \\
\hline
\end{tabular}

* Only factors with eigenvalue above 1 are indicated in the table. Data source: Collected by this research.

An important indicator of the quality of factor analysis is the Kaiser-Meyer-Olkin (KMO) measure of sample adequacy. Its purpose is to check to what extent the sample meets the requirements of the factor analysis, i.e., to answer the question of whether the sample is adequate for the assumptions of the factor analysis. The measure compares partial correlations with 2-coefficient correlation coefficients. $\mathrm{KMO}$ assumes values in the range of $0-1$, with low results indicating that the reduction of variables will be small. It is assumed that the result of $\mathrm{KMO} \geq 0.5$ gives a satisfactory reduction of variables. In the analysis carried out, the KMO measure was 0.919 , which means that the variable reduction model is at a very good level (Table 3).

Table 3. Obtained Kaiser-Meyer-Olkin (KMO) values and Bartlett's sphericity test values.

\begin{tabular}{lll}
\hline \multicolumn{2}{l}{ Kaiser-Meyer-Olkin Measure of Sampling Adequacy } & $\mathbf{0 . 9 1 9}$ \\
\hline \multirow{3}{*}{ Bartlett's Test of Sphericity } & $\begin{array}{l}\text { Approx. } \\
\text { Chi-Square }\end{array}$ & 9683.195 \\
\cline { 2 - 3 } & $\mathrm{df}$ & 435 \\
\cline { 2 - 3 } & Sig. & 0.000 \\
\hline
\end{tabular}

Data source: Collected by this research.

Bartlett's sphericity test (Table 3) was calculated for the same purpose as the KMO measure. This test examines whether there are any significant correlations between variables, verifying that the correlation matrix is a unit matrix. In the case of a significant test result, this hypothesis is rejected and it is assumed that there are correlations between variables, meaning that there are hidden factors. In the case of this study, the sphericity test was $<0.05$ and therefore statistically significant.

Table 4 presents the results of the factor analysis, including the names that the new variables received. Those factor loads that are important for individual factors have been presented. 
Table 4. The obtained matrix of rotational components-factor loadings *

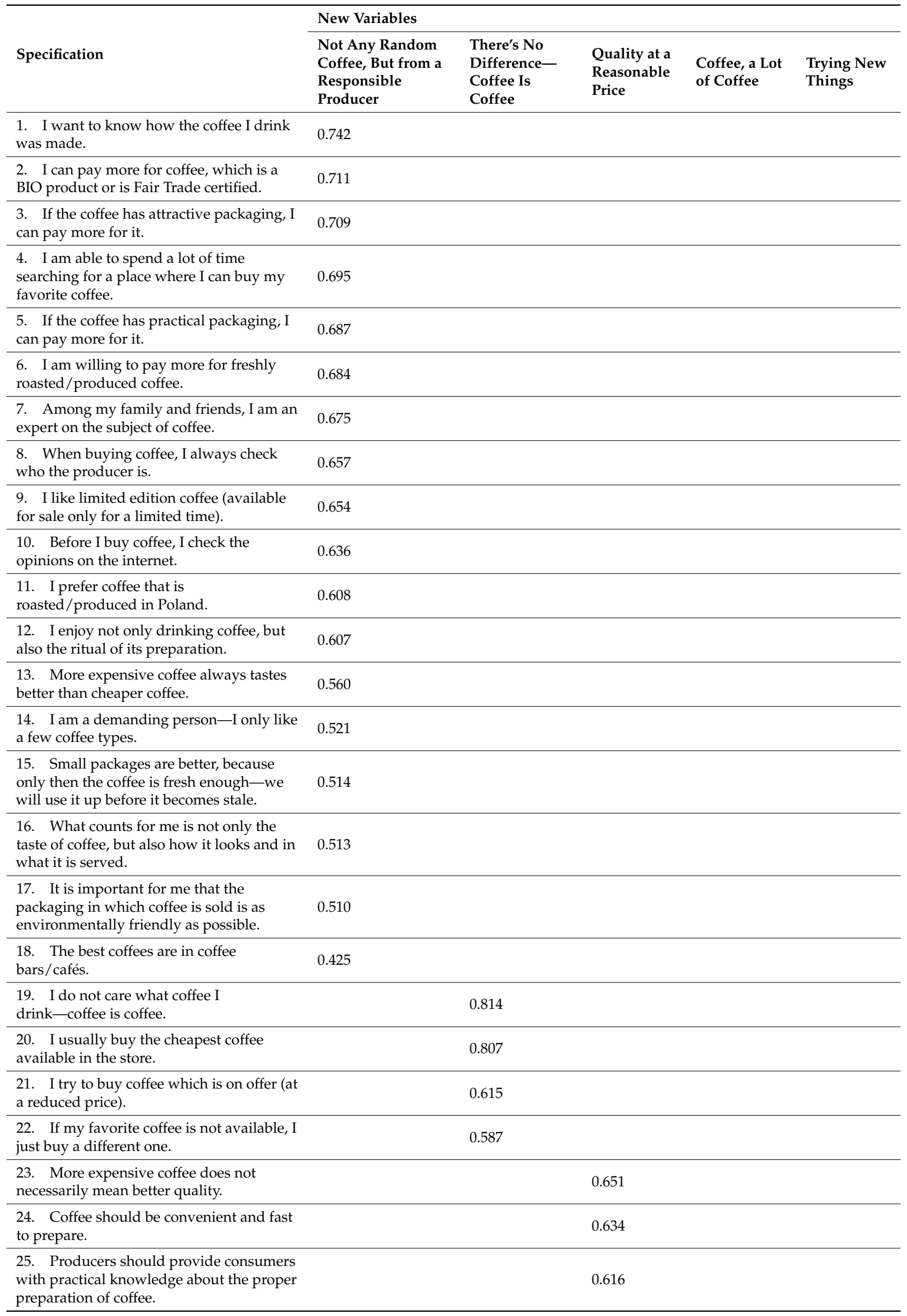


Table 4. Cont.

\begin{tabular}{|c|c|c|c|c|c|}
\hline \multirow[b]{2}{*}{ Specification } & \multicolumn{5}{|l|}{ New Variables } \\
\hline & $\begin{array}{l}\text { Not Any Random } \\
\text { Coffee, But from a } \\
\text { Responsible } \\
\text { Producer }\end{array}$ & $\begin{array}{l}\text { There's No } \\
\text { Difference- } \\
\text { Coffee Is } \\
\text { Coffee }\end{array}$ & $\begin{array}{l}\text { Quality at a } \\
\text { Reasonable } \\
\text { Price }\end{array}$ & $\begin{array}{l}\text { Coffee, a Lot } \\
\text { of Coffee }\end{array}$ & $\begin{array}{l}\text { Trying New } \\
\text { Things }\end{array}$ \\
\hline $\begin{array}{l}\text { 26. I am more willing to choose coffee } \\
\text { that has been on the market for a long time, } \\
\text { has been tried and tested. }\end{array}$ & & & 0.518 & & \\
\hline $\begin{array}{l}\text { 27. It's hard for me to imagine life } \\
\text { without coffee. }\end{array}$ & & & & 0.661 & \\
\hline $\begin{array}{l}\text { 28. Large packages are better because } \\
\text { they are more economical. }\end{array}$ & & & 0.474 & 0.483 & \\
\hline $\begin{array}{l}\text { 29. I'm attached to my favorite coffee and } \\
\text { I'm reluctant to change it. }\end{array}$ & & & 0.401 & & -0.620 \\
\hline $\begin{array}{l}\text { 30. I like to try new coffees when they } \\
\text { appear on the market. }\end{array}$ & & & & & 0.525 \\
\hline
\end{tabular}

As a result of factor analysis, each respondent was assigned results consistent with the new variables obtained by factor analysis.

\subsubsection{Cluster Analysis}

The next step was to conduct cluster analysis, the aim of which was to define the segments, and the analysis itself took place in two stages. The first stage was to perform hierarchical clustering analysis using Ward's method, the second stage was to use the non-hierarchical method. The use of both methods resulted from methodological limitations. Non-hierarchical analysis is less sensitive to observations deviating from the norm and incorrect variables, which enables better results to be obtained. However, the target number of segments needs to be specified (which is not pre-determined). To obtain this information, it is first necessary to perform hierarchical clustering analysis. Analysis of the agglomeration coefficient and the dendrogram, obtained using a layered analysis via Ward's method, led to the selection of 6 segments. After conducting a non-hierarchical analysis, their centroids were finally determined, as shown in Table 5.

Table 5. Final cluster centers.

\begin{tabular}{lllllll}
\hline \multirow{2}{*}{ Specification } & \multicolumn{7}{l}{ Cluster/Segment } & & & \\
\cline { 2 - 7 } & I & II & III & IV & V & VI \\
\hline $\begin{array}{l}\text { Not any random coffee, but } \\
\text { from a responsible producer }\end{array}$ & 1.22992 & 0.01227 & -0.04732 & -0.46716 & 0.49747 & -1.22403 \\
\hline $\begin{array}{l}\text { There's no difference-coffee } \\
\text { is coffee }\end{array}$ & 1.29610 & -0.73632 & 0.30398 & -0.18234 & -0.93130 & 0.53307 \\
\hline Quality at a reasonable price & 0.30222 & 0.11011 & -1.18744 & 0.79579 & 0.18571 & 0.40705 \\
\hline Coffee, a lot of coffee & 0.20172 & 0.78105 & -0.34943 & -1.11779 & -0.02616 & 0.87190 \\
\hline Trying new things & -0.12462 & -1.06431 & -0.06789 & -0.32330 & 0.99031 & 0.78082 \\
\hline
\end{tabular}

Next, names were given to the isolated segments which, in the opinion of the authors, best reflected the behavioral features and the attitude toward the sustainable values of the consumers assigned to the segments. The size of the segments is shown in Table 6. 
Table 6. Size of the segments obtained.

\begin{tabular}{llll}
\hline Cluster/Segment & Name & $\begin{array}{l}\text { Number of } \\
\text { Observations }\end{array}$ & $\begin{array}{l}\text { Percentage of } \\
\text { Observations }\end{array}$ \\
\hline I & $\begin{array}{l}\text { Responsible, } \\
\text { aspiring to be connoisseurs }\end{array}$ & 106.00 & 13.25 \\
\hline II & Loyal coffee enthusiasts & 136.00 & 17.00 \\
\hline III & Pragmatic users & 186.00 & 23.25 \\
\hline IV & Coffee laypersons & 134.00 & 16.75 \\
\hline V & Sophisticated connoisseurs & 134.00 & 16.75 \\
\hline VI & $\begin{array}{l}\text { Consumerists, connoisseurs, } \\
\text { but not at any price }\end{array}$ & 104.00 & 13.00 \\
\hline Valid & & 800.00 & 100.00 \\
\hline Losses & & 0.00 & 0.00 \\
\hline & Data source: Collected by this research.
\end{tabular}

Finally, a description of the segments was made in a broader context, which also included the socio-economic and demographic characteristics of the respondents and their preferences in the coffee market. The description of segments was based on cross tables, which were created as a result of using the IBM SPSS Statistics 24 program.

\section{Analysis of Results}

The first isolated group (segment I) included people whose attitudes and opinions were most in line with the guidelines for sustainable development and sustainable consumption from among all respondents. For more than $80 \%$ of consumers in this group, it was important (the answers "I strongly agree" and "I mostly agree") that the packaging in which the coffee is sold was as environmentally friendly as possible and to know how the coffee they drink was produced. Additionally, over $80 \%$ of respondents in this segment agreed to pay more for coffee sold in packaging that could be re-used in the household or that was large and economical, which meant less packaging. Over $75 \%$ of respondents in this segment were willing to pay more for coffee that was a BIO type product or had a Fairtrade certificate, and when buying coffee, always checked who the producer was. It is difficult for these people to imagine life without coffee and they were of the opinion that the best coffee is served in coffee bars and cafés. Although they were attached to their favorite brand of coffee, if it was not available on the store shelf, they would decide to buy another one to not have to give up their favorite drink. They were happy to choose coffee that was roasted/produced in Poland and were willing to pay more for freshly roasted coffee. They drank ground coffee (38.7\%) almost as often as instant coffee $(35.8 \%)$, which were their most preferred types of coffee. This segment was characterized by an equal share of women and men. Almost half of the people who made up this segment were young people under 35, most often living in towns with less than 100,000 inhabitants who came from households where the net monthly income per person was below 500 euro. Therefore, these consumers could be described as "responsible, aspiring to be connoisseurs", constituting $13.3 \%$ of the sample.

Consumers classified in the second group (segment II) declared an attachment to their favorite coffee and were most often reluctant to change it amongst all of the survey participants. Like consumers in the first group, it was difficult for them to imagine life without coffee. The respondents forming this market segment considered themselves to be demanding - they only liked a few coffee brands as well as coffee experts-and more expensive coffee did not necessarily mean better quality. Coffee beans were the most popular among all segments (25.0\%). Regarding attitude to sustainable values, positive attitudes ("I definitely agree" and "I mostly agree") were identified in less than half of the respondents in this group. This segment was dominated by women (56.6\%), people aged 45 and more $(56.6 \%)$, whose monthly net income per person in their households was in the range of 201-500 euro. 
The respondents forming segment II could therefore be described as "loyal coffee enthusiasts". In the sample, they constituted $17.0 \%$ of respondents.

The third group of respondents was characterized by attachment to their favorite brand of coffee and a reluctance to change. These people liked to drink coffee and it was difficult for them to imagine life without coffee. The segment was dominated by men (55.4\%). Almost half of the respondents in this group were people aged under 35, mainly aged between 16 and 24 (28.5\%). This segment, among all of those isolated, was characterized by the highest share of rural residents (30.1\%). Almost half of the respondents in this group received a monthly net income in the range of 201-500 euro per person. When buying coffee, they usually chose ground coffee (39.8\%) or instant coffee (35.5\%). People in this segment can be described as "pragmatic users" of coffee. They formed the most numerous segment: $23.3 \%$ of all respondents. Among all of the respondents, people in this segment were characterized by the highest indifference toward sustainable values. The responses "I neither agree nor disagree" accounted for as much as $63 \%$ to $70 \%$ of the responses to statements regarding aspects of sustainable development and sustainable consumption.

Segment IV consisted of people who can be described as "coffee laypersons" and constituted $16.8 \%$ of all surveyed coffee consumers. Their market behavior was characterized by attachment to their favorite coffee and an unwillingness to replace it with another brand. Lack of knowledge about the coffee market translated into the purchase of coffee brands that had been on the market for years. In their opinion, coffee products should be convenient and quick to prepare, and producers should provide consumers with practical knowledge about proper coffee preparation. They agreed with the opinion that more expensive coffee did not necessarily mean better quality. As far as their attitude toward sustainable values was concerned, more than half of the respondents in this segment "strongly agree" or "agree" only with the statements "It is important for me that the packaging in which coffee is sold is the most environmentally friendly" (63.4\%) and "Large packaging is better because it is more economical" (56.7\%). In the "coffee layperson" segment, there were slightly more women than men $(51.5 \%)$, and more people in the 45 and over category than those of a younger age. Nearly two thirds of the respondents in this segment were residents of smaller towns (less than 100,000 inhabitants) and villages. Nearly $40 \%$ of the respondents in this group of consumers lived in households where the monthly net income per person was in the range of 301-500 euro. Consumers in this segment usually bought instant coffee (41.0\%).

Consumers classified in the fifth group (segment V) were people who more often than others replied that what counted for them was not only the taste of coffee, but also how it looked and how it was served. It is not just drinking coffee that makes them happy, but also the ritual of preparing it. They can also certainly be included in the group of pioneers as they like to try new products whenever they appear on the market. They could not imagine life without coffee and were willing to pay more for good, freshly roasted coffee. This segment was dominated by women $(56.7 \%)$, people under 55 , inhabitants of larger cities (over 100,000 inhabitants) and relatively well-to-do people. Nearly a third of the respondents in this segment declared a monthly net income of 701 euro and more per person in their households. "Sophisticated connoisseurs", which is how this segment can be described, are characterized by a high consumption of coffee, bought in bean form $(23.1 \%)$, second in this respect, and only slightly, to loyal coffee enthusiasts. In the analyzed sample, they constituted $16.8 \%$ of all respondents. Their attitudes and opinions were the most in line with sustainable values, immediately after the consumers classified in the first segment.

The sixth and last segment of coffee consumers were people who were least guided by the values of sustainable consumption. Over $70 \%$ of the respondents in this group admitted that they did not see any justification in paying more for coffee that was a BIO product or had a Fairtrade certificate. About $60 \%$ did not agree to pay more for coffee sold in practical packaging that could be used later. A similar percentage was not interested in either who produced the coffee they buy or how it was produced. It was important for every sixth respondent in this group that the packaging in which the coffee is sold was environmentally friendly. People in this segment mainly bought coffee currently on sale (offered 
at a reduced price) and chose large packages that they thought were more economical. In their opinion, more expensive coffee did not necessarily mean that the coffee was of good quality, and if the store did not have their favorite brand, they would simply buy another one. Regarding the type of coffee purchased, it was usually ground coffee $(40.4 \%)$ or instant coffee $(37.5 \%)$. This segment had slightly more men than women (52.9\%) and nearly a third aged 35-44, were urban residents (79.0\%), and most often had a monthly net income of 201-500 euro per person in a household. In the studied sample, they constituted the smallest group at 13\% and can be described as "consumerists, connoisseurs, but not at any price."

The synthetic approach to sustainable values in the identified segments of coffee consumers is presented in Table 7.

Table 7. Attitude toward sustainable values in the identified segments ( $n=800$, in \%).

\begin{tabular}{|c|c|c|c|c|c|c|c|}
\hline \multirow{2}{*}{ Specification } & \multirow{2}{*}{ Evaluations } & \multicolumn{6}{|c|}{ Coffee Consumer Segments } \\
\hline & & $\mathbf{I}$ & II & III & IV & $\mathbf{V}$ & VI \\
\hline \multirow{3}{*}{$\begin{array}{l}\text { I can pay more for coffee, which is a BIO type } \\
\text { product or is Fairtrade certified. }\end{array}$} & negative & 3.8 & 38.2 & 20.9 & 46.3 & 15.7 & 70.2 \\
\hline & neutral & 18.9 & 39.0 & 69.4 & 29.1 & 37.3 & 25.0 \\
\hline & positive & 77.4 & 22.8 & 9.7 & 24.6 & 47.0 & 4.8 \\
\hline \multirow{3}{*}{$\begin{array}{l}\text { When buying coffee, I always check who is the } \\
\text { producer. }\end{array}$} & negative & 4.7 & 24.3 & 21.5 & 44.0 & 20.9 & 58.7 \\
\hline & neutral & 17.0 & 34.6 & 64.5 & 33.6 & 29.1 & 25.0 \\
\hline & positive & 78.3 & 41.1 & 14.0 & 22.4 & 50.0 & 16.3 \\
\hline \multirow{3}{*}{ I want to know how the coffee I drink was made. } & negative & 0.9 & 28.0 & 21.5 & 29.8 & 9.0 & 62.5 \\
\hline & neutral & 17.0 & 39.0 & 62.9 & 46.3 & 38.1 & 31.7 \\
\hline & positive & 82.1 & 33.0 & 15.6 & 23.9 & 52.9 & 5.8 \\
\hline \multirow{3}{*}{$\begin{array}{l}\text { It is important for me that the packaging in which } \\
\text { coffee is sold is as environmentally friendly as } \\
\text { possible. }\end{array}$} & negative & 2.8 & 14.0 & 20.4 & 9.0 & 12.0 & 36.6 \\
\hline & neutral & 15.1 & 38.2 & 65.1 & 27.6 & 29.9 & 46.2 \\
\hline & positive & 82.1 & 47.8 & 14.5 & 63.4 & 58.2 & 17.2 \\
\hline \multirow{3}{*}{$\begin{array}{l}\text { If the coffee has practical packaging, I can pay } \\
\text { more for it. }\end{array}$} & negative & 2.8 & 34.6 & 20.9 & 38.8 & 21.7 & 62.5 \\
\hline & neutral & 16.1 & 36.8 & 69.4 & 38.8 & 41.8 & 26.0 \\
\hline & positive & 81.1 & 28.7 & 9.7 & 22.4 & 36.6 & 11.5 \\
\hline \multirow{3}{*}{$\begin{array}{l}\text { Large packages are better because they are more } \\
\text { economical. }\end{array}$} & negative & 0.9 & 2.2 & 13.4 & 13.4 & 26.9 & 4.8 \\
\hline & neutral & 9.4 & 16.9 & 65.1 & 29.9 & 26.1 & 6.8 \\
\hline & positive & 89.7 & 80.9 & 21.5 & 56.7 & 47.0 & 88.4 \\
\hline
\end{tabular}

* On a five-point Likert scale, where a score of 1 means "I strongly disagree" and a score of 5 means "I strongly agree". Negative opinions denote a total of indications from 1 to 2, neutral is 3 , and positive indications from 4 to 5 . Data source: Collected by this research.

\section{Discussion}

This research indicated that over 13\% of coffee consumers in Poland could be categorized in segment I as "responsible, aspiring to be connoisseurs". Thus, their attitudes and opinions are consistent with the guidelines of sustainable development and sustainable consumption. The results of our research are also in line with the findings of the Institute for Sustainable Development in Warsaw [55], which, in the years 1992-2011, conducted regular surveys of the environmental awareness of Polish citizens. These studies showed that the sense of individual impact on the environment among consumers of food products is increasing, and the frequency of declaring pro-ecological behaviors is also increasing. In addition, these studies have shown that sustainable purchasing decisions are influenced by sustainable values because environmental protection is mainly motivated by caring for one's own health and the health of future generations (two-thirds of respondents) as well as caring for nature as a value in itself (this answer was marked by every fourth Pole). The most environmentally friendly respondents included people with a higher education, lived in big cities, and were representatives of management, mid-level personnel and technicians, administrative and office staff, and self-employed persons. On the basis of the Institute's research, five types of consumers 
of food products were also specified, depending on their environmental awareness and attitude toward sustainable consumption. The isolated consumer types were largely consistent with the coffee consumer segments identified by the authors (Table 8).

Table 8. Types of consumers of food products in connection with segments of coffee consumers in Poland.

\begin{tabular}{|c|c|c|}
\hline \multicolumn{2}{|c|}{$\begin{array}{l}\text { Types of Consumers of Food Products According to the Research of } \\
\text { the Institute for Sustainable Development in Warsaw }\end{array}$} & \multirow{2}{*}{$\begin{array}{l}\text { Coffee Consumer Segment } \\
\text { Isolated by the Authors }\end{array}$} \\
\hline Consumer Type & Level of Ecological Knowledge and Awareness & \\
\hline Black & $\begin{array}{l}\text { Lack of ecological knowledge and awareness; } \\
\text { follower of the cult of materialism; does not } \\
\text { consume food economically (overconsumption) }\end{array}$ & $\begin{array}{l}\text { Segment VI- "Consumerists, } \\
\text { connoisseurs but not at any price" }\end{array}$ \\
\hline Grey & $\begin{array}{l}\text { Low level of ecological knowledge and awareness; } \\
\text { the average consumer; saves food for economic } \\
\text { reasons only }\end{array}$ & $\begin{array}{l}\text { Segment IV "coffee laypersons" } \\
\text { Segment III-"pragmatic users" } \\
\text { Segment II-" loyal coffee } \\
\text { enthusiasts" }\end{array}$ \\
\hline Grey-green & $\begin{array}{l}\text { Significant ecological knowledge; susceptible to } \\
\text { raising ecological awareness; wants to be perceived } \\
\text { as green, economical in the consumption of food } \\
\text { for economic or snobbish reasons }\end{array}$ & $\begin{array}{l}\text { Segment V-"sophisticated } \\
\text { connoisseurs" } \\
\text { Segment I-"responsible, aspiring } \\
\text { to be connoisseurs" }\end{array}$ \\
\hline Green & $\begin{array}{l}\text { A lot of ecological knowledge, constantly } \\
\text { expanding their ecological awareness, wants to } \\
\text { change and changes their lifestyle in order to } \\
\text { protect the environment, carefully consumes food, } \\
\text { use resources to protect them }\end{array}$ & $\begin{array}{l}\text { Segment I-“responsible, aspiring } \\
\text { to be connoisseurs" }\end{array}$ \\
\hline Bright green & $\begin{array}{l}\text { Sometimes poses a threat of "green totalitarianism"; } \\
\text { postulates a return to nature; very economical in } \\
\text { the consumption of food and the use of resources }\end{array}$ & - \\
\hline
\end{tabular}

Data source: Own study based on [55].

However, it turns out that not all coffee producers in Poland are fully aware of this. Looking through the missions and offers of 23 coffee producers in Poland, it can be seen that only a four undertook large-scale activities in Poland that fit into the concept of sustainable development, as well as social and ecological responsibility. In their strategic documents, these producers committed themselves to the ethical conduct of business, both in regard to the environment, growers, local communities, consumers, and their own employees. They offered the highest quality coffee, paying special attention to its taste and aroma, but at the same time, advocating for the protection of the environment and better living conditions for farmers cultivating coffee.

The research also showed that over $75 \%$ of the respondents classified in segment I were willing to pay more for coffee that was a BIO-type product or had a Fairtrade certificate [56]. The activities carried out by the largest coffee producers in Poland may provide valuable advice for other Polish producers who are interested in preparing an attractive offer for those in segment I on the basis of the research carried out. To prepare such an offer, in the authors' opinion, activities should focus on four key areas:

- Support for growers. In the 21st century, in order to respond to the challenges facing the coffee market, producers should teach small growers how to operate in a more effective way and how to use sustainable crop methods, thus increasing their productivity over a longer period of time [57-59].

- Cooperation with standardization organizations such as the Rainforest Alliance, Fairtrade, UTZ Certified or other national or global organizations behind the organic BIO mark $[60,61]$. 
This also supports research provided by Ingenbleek and Reinders on the coffee market in the Netherlands [62].

- Environmental protection to achieve the best quality coffee. Coffee is a valuable resource. Fertile soil, clean water, and suitable climatic conditions are key requirements for its quality and quantity. Knowledge on environmentally friendly cultivation methods is often limited. Coffee producers in Poland should engage in initiatives such as Coffee \& Climate, which deals with climate change and the best possible adaptation for farmers cultivating coffee and their methods to the local effects of these changes [63].

- Educational projects in coffee-growing countries. Growers and their families are often exposed to difficult social conditions. Therefore, coffee producers in Poland should engage more often in the rights of children, for example, in projects such as Save the Children, a campaign consisting in organizing practical and vocational educational activities to prepare students in Tanzania, for example, to start a professional activity related to growing coffee [64].

At the same time, coffee producers in Poland should not neglect the consumers who are not guided by sustainable values in the process of purchasing coffee (segments II, III, IV, VI). They should undertake marketing activities aimed at changing their attitude toward sustainable consumption. These activities should be mainly related to the instruments of mix marketing, such as price and promotion. This was confirmed by surveys carried out in 2014 on a sample of 500 adult residents of the Silesian Province in Poland by Jaros [65] regarding the assessment of compliance of consumer behavior with the principles of sustainable consumption. The research showed that for a large group of coffee consumers in Poland, sustainable consumption was too expensive, which was confirmed by the study conducted by Risius et al. on a group of 447 German consumers of fish [66]. However, a different view was presented by Arnot et al. [67]. Their results showed that when sustainable production of coffee increased the price of coffee, consumer responses were smaller than in the event of increase of conventional coffee prices [68]. Similar conclusions were reached by Cranfield et al. [69], whose research was conducted in Vancouver and Toronto. The results showed that consumers in both cities were willing to pay more for coffee with a Fairtrade certificate. As shown by research conducted in Italy by Cosmina et al., the success of Fairtrade coffee depends on the willingness of consumers to pay a premium price for ethical attributes [70-72]. Jaros [65] also identified other factors that, in her opinion, constituted barriers to sustainable consumption. These barriers, according to the author, are also crucial for the sustainable behavior of consumers in the coffee market in Poland (Table 9).

Table 9. Main obstacles to sustainable consumption in the opinion of the surveyed inhabitants of the Silesian Province $(n=500)$.

\begin{tabular}{lllllll}
\hline \multirow{2}{*}{$\begin{array}{l}\text { Main Obstacles to Sustainable } \\
\text { Consumption }\end{array}$} & \multicolumn{7}{l}{$\begin{array}{l}\text { 1-the Most Significant Reason, 5-the Least Significant } \\
\text { Reason }\end{array}$} & $\mathbf{1}$ & $\mathbf{2}$ & $\mathbf{3}$ & $\mathbf{4}$ & $\mathbf{5}$ & Average \\
\cline { 2 - 7 } & $55.6 \%$ & $21.0 \%$ & $12.6 \%$ & $4.4 \%$ & $6.4 \%$ & 1.9 \\
\hline Requires too much time & $47.6 \%$ & $23.8 \%$ & $14.8 \%$ & $5.8 \%$ & $8.0 \%$ & 2.0 \\
Requires too much effort & $68.8 \%$ & $11.0 \%$ & $7.6 \%$ & $4.4 \%$ & $8.2 \%$ & 1.7 \\
Too expensive & $11.4 \%$ & $25.2 \%$ & $23.0 \%$ & $14.8 \%$ & $25.6 \%$ & 3.2 \\
There are no such products on the market & $39.0 \%$ & $21.8 \%$ & $16.0 \%$ & $14.0 \%$ & $9.2 \%$ & 2.3 \\
No information on how to do it & $6.8 \%$ & $7.0 \%$ & $16.2 \%$ & $21.8 \%$ & $48.2 \%$ & 4.0 \\
Others don't do it & Data source: [65]. & & & \\
\hline
\end{tabular}

According to Jaros [65], in addition to the price, a significant obstacle, as indicated by more than half of the respondents as the most significant reason, was the need to devote more time to consumer behavior (e.g., related to the search for ecological products or their preparation for consumption). The respondents wanted to emphasize that sustainable consumption took longer than ordinary, standard consumption. Nevertheless, the effort that should be put into practicing sustainable 
consumption turned out to be important; this obstacle proved to be very significant for $47.6 \%$ of the respondents. A large group of respondents also emphasized the importance of the lack of information on how to practice sustainable consumption. The least important were the two obstacles related to the availability of sustainable products on the market and not noticing this type of behavior in others. The barriers mentioned may be an important indication for coffee producers who are willing to shape the behavior of coffee consumers in Poland, so that they fit even more firmly into the concept of sustainable consumption.

\section{Conclusions}

\subsection{Theoretical Contribution}

The research and statistical analysis of our results allowed the hypothesis that was set in the introduction to be accepted. The sustainable values included in the study, such as environmental protection, the ethical behavior of producers, fair trade, or maximizing the usability of consumption, can, and should, be used as segmentation criteria in the coffee market. What was proven was that the attitude of the respondents to these values, in statistical terms, significantly differentiated the consumer groups, distinguishing a segment to whom not only a better quality of life was important, but who were also concerned for the natural environment and the ability to meet the needs of future generations. It is worth emphasizing that segments of coffee consumers guided by sustainable values ("responsible") and those who disagreed with them ("consumerists") constituted two extreme clusters of the least similar individuals. This more clearly demonstrates the importance of sustainable values as variables differentiating consumer behavior in the coffee market, thus contributing to the development of consumer behavior theory in this field.

\subsection{Practical and Social Implications}

The obtained research results confirmed the existence of a segment of coffee consumers whose purchasing decisions were based on sustainable values. This fact has both practical and social implications. From the practical perspective, it shows coffee producers and sellers that there is a market segment that is environmentally conscious and, therefore, actively looks for sustainable products. The knowledge of the existence of such a market segment, as well as its size and socio-economic-demographic features, may be the source of competitive advantage for such enterprises, at the same time, motivating them to act for sustainable development. Social implications, on the other hand, stem from the mere size of the sustainability-conscious segment. The obtained research results indicate that it comprises only $13.3 \%$ of coffee consumers. Therefore, it is a signal for social, governmental, and non-governmental institutions, whose mission it is to promote the idea of sustainable development and sustainable consumption, to increase their educational activities toward promoting environmentally-friendly consumer behavior that is oriented not only toward the satisfaction of one's own short-term needs, but also toward the concern for future generations. After all, we must remember that we-the contemporary generation— did not inherit our planet from our ancestors, but borrow it from our successors.

\subsection{Limitations and Future Research Directions}

The authors of the article are aware that, although the research was carried out by consumers across all 16 provinces of Poland, it cannot be considered as fully representative. According to the authors, the presented results may, however, provide interesting conclusions about the demographic, economic, psychographic, or behavioral characteristics of coffee consumers, while providing input to the discussion on the importance of sustainable consumption and sustainable development in consumer decisions and choices in the coffee market.

An important research task would be to confirm the results obtained in these studies by using a representative sample of consumers selected randomly, and to conduct similar research among coffee 
consumers from other countries. It would also be important and interesting to conduct further research on the impact of sustainable values on consumer behavior in markets for other goods and services.

Author Contributions: Conceptualization, G.M., Ł.W. and S.M.; Data curation, G.M., Ł.W. and S.M.; Formal analysis, G.M., Ł.W. and S.M.; Funding acquisition, G.M., Ł.W. and S.M.; Investigation, G.M., Ł.W. and S.M.; Methodology, G.M., Ł.W. and S.M.; Project administration, G.M., Ł.W. and S.M.; Resources, G.M., Ł.W. and S.M.; Software, G.M., Ł.W. and S.M.; Supervision, G.M., Ł.W. and S.M.; Validation, G.M., Ł.W. and S.M.; Visualization, G.M., Ł.W. and S.M.; Writing—original draft, G.M., Ł.W. and S.M.; Writing—review \& editing, Ł.W. and S.M.

Funding: The funders (Mokate SA) had no role in the design of the study; in the collection, analyses, or interpretation of data; in the writing of the manuscript, or in the decision to publish the results.

Conflicts of Interest: The authors declare no conflict of interest.

\section{References}

1. Munguia, N.; Varela, A.; Esquer, J.; Velázquez Contreras, L.E. Fostering corporate sustainability in the Mexican coffee industry. Psu Res. Rev. 2017, 1, 51-62. [CrossRef]

2. Gonzalez-Perez, M.A.; Gutierrez-Viana, S. Cooperation in coffee markets: The case of Vietnam and Colombia. J. Agribus. Dev. Emerg. Econ. 2012, 2, 1. [CrossRef]

3. DaMatta, F.M.; Ramalho, J.D.C. Impacts of drought and temperature stress on coffee physiology and production: A review. Braz. J. Plant Physiol. 2006, 18, 55-81. [CrossRef]

4. International Coffee Organization. Coffee Market Report; London, UK, 2018; Available online: www.ico.org (accessed on 19 January 2019).

5. Mintel Group. Coffee Global Annual Report; London, UK, 2018.

6. Chudy, S. Development of Coffee Market and Changes in Coffee Consumption Among Poles. J. Agribus. Rural Dev. 2014, 4, 41-51.

7. Ministry of Treasury Republic of Poland, The Overview of Polish Coffee Market. Available online: https://www.msp.gov.pl/en/polish-economy/economic-news/5634, The-overview-of-Polishcoffee-market.html (accessed on 19 December 2018).

8. Peštek, A.; Agic, E.; Cinjarevic, M. Segmentation of organic food buyers: An emergent market perspective. Br. Food J. 2018, 120, 269-289. [CrossRef]

9. Dibb, S.; Stern, P.; Wensley, R. Marketing knowledge and the value of segmentation. Mark. Intell. Plan. 2002, 20, 113-119. [CrossRef]

10. Wedel, M.; Kamakura, W. Market Segmentation—Conceptual and Methodological Foundations; Kluwer Academic Publishers: Boston, MA, USA, 2000.

11. do Paço, A.; Raposo, M. "Green" segmentation: An application to the Portuguese consumer market. Mark. Intell. Plan. 2009, 27, 364-379. [CrossRef]

12. Obilo, O.O.; Alford, B.L. Market segmentation via attitudinal functions: A multimethod approach. Qual. Mark. Res. Int. J. 2018, 21, 63-81. [CrossRef]

13. Sowell, T. Basic Economics: A Common Sense Guide to the Economy; Basic Books: New York, NY, USA, 2007.

14. Lutz, C.; Newlands, G. Consumer segmentation within the sharing economy: The case of Airbnb. J. Bus. Res. 2018, 88, 187-196. [CrossRef]

15. Arunachalam, D.; Kumar, N. Benefit-based consumer segmentation and performance evaluation of clustering approaches: An evidence of data-driven decision-making. Expert Syst. Appl. 2018, 11, 11-34. [CrossRef]

16. Halkos, G. Advances in Green Economy and Sustainability: Introduction. Int. J. Innov. Sustain. Dev. 2018, 12, 247-257.

17. Simons, P. A green economy? Koers Bull. Christ. Scholarsh. 2014, 79, 1-8. [CrossRef]

18. Mont, O.; Plepys, A. Sustainable consumption progress: Should we be proud or alarmed? J. Clean. Prod. 2008, 16, 531-537. [CrossRef]

19. Veleva, V.; Ellenbecker, M. Indicators of sustainable production: Framework and methodology. J. Clean. Prod. 2001, 9, 519-549. [CrossRef]

20. Tukker, A.; Cohen, M.J.; Hubacek, K.; Mont, O. Sustainable Consumption and Production. J. Ind. Ecol. 2010, 14, 1-3. [CrossRef] 
21. Communication from the Commission to the European Parliament, the Council, the European Economic and Social Committee and the Committee of the Regions on the Sustainable Consumption and Production and Sustainable Industrial Policy Action Plan, 2008. Available online: http:// zielonasiec.pl/en/ (accessed on 10 December 2018).

22. Alliance of Associations Polish Green Network. Available online: https:/ / eur-lex.europa.eu/legal-content/ EN/ALL/?uri=CELEX:52008DC0397 (accessed on 10 December 2018).

23. Evans, D. Consuming conventions: Sustainable consumption, ecological citizenship and the worlds of worth. J. Rural Stud. 2011, 27, 109-115. [CrossRef]

24. Ministry of Entrepreneurship and Technology Republic of Poland. Available online: http:/ / www.mpit.gov. $\mathrm{pl}$ /strony/zadania/zrownowazony-rozwoj/slad-srodowiskowy/ (accessed on 19 January 2019).

25. Caeiro, S.; Ramos, T.B.; Huisingh, D. Procedures and criteria to develop and evaluate household sustainable consumption indicators. J. Clean. Prod. 2012, 27, 72-91. [CrossRef]

26. Balderjahn, I.; Peyer, M.; Seegebarth, B.; Wiedmann, K.P.; Weber, A. The many faces of sustainability-conscious consumers: A category-independent typology. J. Bus. Res. 2018, 91, 83-93. [CrossRef]

27. Mazanec, J.; Strasser, H. A Nonparametric Approach to Perceptions-Based Market Segmentation: Foundations; Springer: Berlin, Germany, 2000.

28. Brunner, T.A.; Siegrist, M. A consumer-oriented segmentation study in the Swiss wine market. Br. Food J. 2011, 113, 353-373. [CrossRef]

29. Dolnicar, S.; Leisch, F. Segmenting markets by bagged clustering. Australas. Mark. J. 2004, 12, 51-65. [CrossRef]

30. Ryan, I.; Cowan, C.; McCarthy, M.; O'Sullivan, C. Segmenting Irish food consumers using the food-related lifestyle instrument. J. Int. Food Agribus. Mark. 2004, 16, 89-114. [CrossRef]

31. McDonald, M.; Dunbar, I. Market Segmentation: How to Do It, How to Profit from It; Elsevier: Oxford, UK; Burlington, VT, USA, 2004.

32. Dolnicar, S. Using cluster analysis for market segmentation-Typical misconceptions, established methodological weaknesses and some recommendations for improvement. Australas. J. Mark. Res. 2003, 11, 5-12.

33. Steenkamp, J.E.M.; Ter Hofstede, F. International market segmentation: Issues and perspectives. Int. J. Res. Mark. 2002, 19, 185-213. [CrossRef]

34. Ahmad, R. Benefit segmentation: A potentially useful technique of segmenting and targeting older consumers. Int. J. Mark. Res. 2003, 45, 373-388.

35. Wróblewski, Ł.; Mokrysz, S. Consumer Preferences for Coffee Types and Coffee Bean Brands Available on the Polish Market. J. Adv. Soc. Sci. Humanit. 2017, 3, 36352-36362.

36. Maciejewski, G.; Mokrysz, S.; Wróblewski, Ł. Consumer preferences for coffee brands available on the polish market-Comparative analysis. Mark. I Rynek 2018, 4, 27-39.

37. Wróblewski, Ł.; Dacko-Pikiewicz, Z. Sustainable Consumer Behaviour in the Market of Cultural Services in Central European Countries: The Example of Poland. Sustainability 2018, 10, 3856. [CrossRef]

38. Cahill, D.J. Target marketing and segmentation: Valid and useful tools for marketing. Manag. Decis. 1997, 35, 10-13. [CrossRef]

39. Cahill, D.J. Lifestyle Market Segmentation; Haworth Press: New York, NY, USA, 2006.

40. Ariadna, Questions and Answers. Available online: https://panelariadna.pl/faq (accessed on 7 December 2018).

41. Ariadna, Rules for Participation in the Ariadna Research Program. Available online: https://panelariadna.pl (accessed on 9 January 2019).

42. Centrum Badania Opinii Społecznej, Zachowania Żywieniowe Polaków, Warszawa 2014. Available online: https:/ / www.cbos.pl/SPISKOM.POL/2014/K_115_14.PDF (accessed on 19 January 2019).

43. INSE Research, Rynek Kawy. Available online: http://research.inse.pl/images/pdf/rynek\%20kawy\% 20inse\%20research.pdf (accessed on 19 January 2019).

44. Maciejewski, G. The meaning of perceived risk in purchasing decisions of the polish customers. Sci. Ann. "Alexandru Ioan Cuza" Univ. Iasieconomic Sci. 2011, 58, 280-304.

45. Putler, D.S.; Krider, R.E. Customer and Business Analytics: Applied Data Mining for Business Decision Making Using R.; CRC Press Taylor \& Francis Group: Boca Raton, USA, 2012. 
46. Sarstedt, M.; Mooi, E. Cluster Analysis. In A Concise Guide to Market Research; Sarstedt, M., Mooi, E., Eds.; Springer Texts in Business and Economics; Springer: Berlin/Heidelberg, Germany, 2014; pp. 273-324.

47. Dolnicar, S. A Review of Unquestioned Standards in Using Cluster Analysis for Data-driven Market Segmentation. In Proceedings of the Australian and New Zealand Marketing Academy Conference 2002, Deakin University, Melbourne, Australia, 2-4 December 2002; Available online: https:/ / ro.uow.edu.au/cgi/ viewcontent.cgi? article=1286\&context=commpapers (accessed on 17 December 2018).

48. Maciejewski, G. Consumers' attitudes toward modern solutions in the retail trade. Econ. Bus. Rev. 2018, 4, 69-85. [CrossRef]

49. Litz, H.P. Multivariate Statistische Methoden und Ihre Anwendung in der Wirtschaft und Sozialwissenschaften; R. Oldenbourg Verlag: München, Germany; Wien, Austria, 2000.

50. Everitt, B.S.; Landau, S.; Leese, M.; Stahl, D. Cluster Analysis, 5th ed.; John Wiley \& Sons, Ltd.: Chichester, UK, 2011.

51. Papista, E.; Chrysochou, P.; Krystallis, A.; Dimitriadis, S. Types of value and cost in consumer-green brands relationship and loyalty behaviour. J. Consum. Behav. 2018, 17, 101-113. [CrossRef]

52. Borin, N.; Lindsey-Mullikin, J.; Krishnan, R. An analysis of consumer reactions to green strategies. J. Prod. Brand Manag. 2013, 22, 118-128. [CrossRef]

53. Mróz, B. Consumerism vs. sustainability: The emergence of new consumer trends in Poland. Int. J. Econ. Policy Emerg. Econ. 2010, 3, 1-15.

54. Wróblewski, Ł.; Mokrysz, S. Consumer Preferences for Coffee Brands Available on the Polish Market. Forum Sci. Oeconomia 2018, 6, 75-90.

55. The Institute for Sustainable Development in Warsaw. Available online: http://www.ine-isd.org.pl/wpcontent/uploads/pdf/badanie_swiad_ekol_polakow_.pdf (accessed on 17 December 2018).

56. Jones, E. Consumer Preferences for Coffee: Hot and Wet, or Quality and Flavor? J. Food Prod. Mark. 2016, 22, 350-380. [CrossRef]

57. Kolk, A. Mainstreaming sustainable coffee. Sustain. Dev. 2013, 21, 324-337. [CrossRef]

58. Raynolds, L.T. Mainstreaming Fair Trade coffee: From partnership to traceability. World Dev. 2009, 37, 1083-1093. [CrossRef]

59. Szczepańska-Woszczyna, K. Responsible leadership contribution to human resource management-a study of csr-hr interface. Procedia Econ. Financ. 2015, 34, 403-409. [CrossRef]

60. Basu, A.K.; Hicks, R.L. Label performance and the willingness to pay for Fair Trade coffee: A cross-national perspective. Int. J. Consum. Stud. 2008, 32, 470-478. [CrossRef]

61. De Pelsmacker, P.; Janssens, W.; Sterckx, E.; Mielants, C. Consumer preferences for the marketing of ethically labelled coffee. Int. Rev. Public Non Profit Mark. 2005, 22, 512-530. [CrossRef]

62. Ingenbleek, P.T.M.; Reinders, M.J.J. The Development of a Market for Sustainable Coffee in The Netherlands: Rethinking the Contribution of Fair Trade. J. Bus. Ethics 2013, 113, 461-474. [CrossRef]

63. Asioli, D.; Nćs, T.; Granli, B.S.; Almli, V.L. Consumer preferences for iced coffee determined by conjoint analysis: An exploratory study with Norwegian consumers. Int. J. Food Sci. Technol. 2014, 49, 1565-1571. [CrossRef]

64. Sepúlveda, W.S.; Chekmam, L.; Maza, M.T.; Mancilla, N.O. Consumers' preference for the origin and quality attributes associated with production of specialty coffees: Results from a cross-cultural study. Food Res. Int. 2016, 89, 997-1003. [CrossRef]

65. Jaros, B. Koncepcja Zrównoważonej Konsumpcji-Problemy Implementacji w Polsce. Ph.D. Thesis, Uniwersytet Ekonomiczny we Wrocławiu, Wrocław, Poland, 2014.

66. Risius, A.; Hamm, U.; Janssen, M. Target groups for fish from aquaculture: Consumer segmentation based on sustainability attributes and country of origin. Aquaculture 2018, 499, 341-347. [CrossRef]

67. Arnot, C.; Boxall, P.C.; Cash, S.B. Do ethical consumers care about price? A revealed preference analysis of fair trade coffee purchases. Can. J. Agric. Econ. 2006, 54, 555-565. [CrossRef]

68. Wann, J.-W.; Kao, C.-Y.; Yang, Y.-C. Consumer Preferences of Locally Grown Specialty Crop: The Case of Taiwan Coffee. Sustainability 2018, 10, 2396. [CrossRef]

69. Cranfield, J.; Henson, S.; Northey, J.; Masakure, O. An assessment of consumer preference for fair trade coffee in Toronto and Vancouver. Agribusiness 2010, 26, 307-325. [CrossRef]

70. Cosmina, M.; Gallenti, G.; Marangon, F.; Troiano, S. Consumers' preferences for ethical attributes of coffee: A choice experiment in the Italian market. Riv. Di Econ. Agrar. (Suppl.) 2016, 16, 314-324. 
71. Maietta, O.W. The hedonic price of fair trade coffee for Italian consumer. Cah. Options Méditerrannées 2005, 64, 45-55.

72. Danielis, R.; Rotaris, L. Willingness to pay for fair trade coffee: A conjoint analysis experiment with Italian consumers. J. Agric. Food Ind. Organ. 2011, 9, 1-20. 